\title{
Ethylene signaling via Ethylene Response Factors (ERFs) modifies wood development in hybrid aspen
}

\author{
Judith Felten ${ }^{1}$, Jorma Vahala², Jonathan Love', András Gorzsás', Lorenz Gerber', Manoj Kumar ${ }^{1}$, \\ Jaakko Kangasjärvi' ${ }^{2}$ Björn Sundberg ${ }^{1^{*}}$ \\ From IUFRO Tree Biotechnology Conference 2011: From Genomes to Integration and Delivery \\ Arraial d'Ajuda, Bahia, Brazil. 26 June - 2 July 2011
}

\section{Background}

The phytohormone ethylene (ET) has the potential to regulate secondary growth of plants and wood formation in trees. Application of exogenous ethylene or its in planta precursor, 1-aminocyclopropane-1-carboxylic acid (ACC), to wood forming tissues of hybrid aspen (Populus tremula $x$ Populus tremuloides) enhances xylem growth [1]. In the same study it was demonstrated that stimulation of enhanced xylem formation (tension wood, TW) at the upper side of leaning stems is mediated by endogenous ET. The production of endogenous ET in TW forming tissues is further supported by the increase of ACC oxidase gene transcript and enzyme activity on the TW side [2].

The ET perception and signal transmission cascade in Arabidopsis has been linked to the transcriptional activation of Ethylene Response Factors (ERFs) [3,4]. As transcription factors, ERFs regulate the expression of various specific downstream target genes by binding to cis-elements in their promoters [5]. We hypothesize that ERFs participate in xylem development through ethylene signaling and that they are involved in ET responses during TW formation.

\section{Results and conclusions}

We identified 169 ERF genes in the Populus trichocarpa genome versions 2.0 and 2.2 using regular expression method and pfam search for the ERF domain. These ERFs grouped into 11 distinct groups, similar to ERFs

\footnotetext{
* Correspondence: Bjorn.Sundberg@genfys.slu.se

'Umeå Plant Science Center, Department of Forest Genetics and Plant Physiology, Swedish University of Agricultural Sciences, SE-901 83 Umeå, Sweden

Full list of author information is available at the end of the article
}

identified in Arabidopsis and rice [6]. Using qPCR we showed that a majority of the ERF transcripts were detectable in stem tissues of in vitro or greenhouse grown hybrid aspen. The responsiveness of all ERFs to short term ACC treatments (10h, in vitro plants) and to short or long term ethylene treatments (24 or 2 weeks, greenhouse grown plants), was assessed by qPCR. Most of the $E R F \mathrm{~s}$ responded to at least one of the treatments, mostly by increased transcript accumulation. We identified $E R F \mathrm{~s}$ that were specifically induced within the early $\mathrm{ACC} / \mathrm{ET}$ - or the late ET-response. In addition, some $E R F$ s showed prolonged induction up to 2 weeks of ET treatment. These different transcript patterns indicate that different $E R F \mathrm{~s}$ may be involved in distinct, temporally distinguished processes during the ACC/ETinduced secondary xylem growth response.

According to their expression and capacity to be induced by ET or ACC, we selected $26 E R F$ candidates and investigated whether those were responsive to endogenous ET-signals in leaned stems during TW formation. We compared the induction of those 26 candidate $E R F \mathrm{~s}$ in TW with $E R F$ accumulation during long-term (2 weeks) ET treatment. Interestingly, a significant overlap of $E R F$ induction in both conditions was found. From the $20 E R F \mathrm{~s}$ that were induced after long-term ET treatment, 16 had an increased transcript abundance during tension wood formation. This indicates that on an $E R F$ transcript basis, tension wood formation is largely comparable to a long-term ET treatment.

Based on the transcript data, twenty ERFs were selected for overexpression in hybrid aspen cambium/ xylem under the $p L M X 5$ promoter [1]. Successful overexpression of the selected ERFs in transgenic plants was confirmed and two to seven lines of each overexpressed 
ERF were phenotyped in a greenhouse trial. In general, ERF overexpression caused only mild alterations of overall plant stature (height and radial growth). Only overexpression of one ERF candidate led to a severe dwarf phenotype with thin stems, reduced fiber and vessel size, reduced height growth and smaller leaves. The absence of any striking phenotypes in all other plants suggests that other regulators in addition to the overexpressed ERFs may be necessary to mimic the enhanced growth response observed during ET/ACC/TW mediated stimulation of secondary xylem growth.

A Fourier-Transformed Infrared spectroscopic and Pyrolysis GC-MS based screening of five lines for each of the 20 overexpressed ERFs revealed that five ERFs led to changes in cell wall composition in xylem tissues when overexpressed. This suggests that these ERFs have the ability to modify cell wall composition in wood forming tissues and may regulate the expression of cellwall biosynthesis genes. This hypothesis is now under further investigation.

\section{Author details}

${ }^{1}$ Umeå Plant Science Center, Department of Forest Genetics and Plant Physiology, Swedish University of Agricultural Sciences, SE-901 83 Umeå, Sweden. ${ }^{2}$ Department of Biosciences, Division of Plant Biology, University of Helsinki, PO Box 65, Fl-00014 Helsinki, Finland.

Published: 13 September 2011

\section{References}

1. Love J, Björklund S, Vahala J, Hertzberg M, Kangasjärvi J, Sundberg B: Ethylene is an endogenous stimulator of cell division in the cambial meristem of Populus. Proc Natl Acad Sci U S A 2009, 106(14):5984-5989.

2. Andersson-Gunnerås S, Hellgren JM, Björklund S, Regan S, Moritz T, Sundberg B: Asymmetric expression of a poplar ACC oxidase controls ethylene production during gravitational induction of tension wood. Plant J 2003, 34(3):339-349.

3. Chao Q, Rothenberg M, Solano R, Roman G, Terzaghi W, Ecker JR: Activation of the ethylene gas response pathway in Arabidopsis by the nuclear protein ETHYLENE-INSENSITIVE3 and related proteins. Cell 1997, 89(7):1133-1144

4. Solano R, Stepanova A, Chao Q, Ecker JR: Nuclear events in ethylene signaling: a transcriptional cascade mediated by ETHYLENE-INSENSITIVE3 and ETHYLENE-RESPONSE-FACTOR1. Gene Dev 1998, 12(23):3703-3714.

5. Ohme-Takagi $M$, Shinshi $H$ : Ethylene-inducible DNA binding proteins that interact with an ethylene-responsive element. Plant Cell 1995, 7(2):173-182.

6. Nakano T, Suzuki K, Fujimura T, Shinshi H: Genome-wide analysis of the ERF gene family in Arabidopsis and rice. Plant Physiol 2006, 140(2):411-432.

doi:10.1186/1753-6561-5-S7-I15

Cite this article as: Felten et al:: Ethylene signaling via Ethylene Response Factors (ERFs) modifies wood development in hybrid aspen. BMC Proceedings 2011 5(Suppl 7):115.

\section{Submit your next manuscript to BioMed Central} and take full advantage of:

- Convenient online submission

- Thorough peer review

- No space constraints or color figure charges

- Immediate publication on acceptance

- Inclusion in PubMed, CAS, Scopus and Google Scholar

- Research which is freely available for redistribution

Submit your manuscript at www.biomedcentral.com/submit
C Biomed Central 